\title{
Crop Establishment with Conservation Tillage on Viable Weed Seed Density and Diversity in Soil, Crop and Water Productivity under RWCS in North-West IGP: A Review
}

\author{
Shivangi $^{1 *}$, Vivek ${ }^{1}$, R. K. Naresh ${ }^{1}$, D. K. Singh ${ }^{1}$ and P. K. Singh ${ }^{2}$ \\ ${ }^{1}$ Department of Agronomy, Sardar Vallabhbhai Patel University of Agriculture \& Technology, \\ Meerut, U. P., India \\ ${ }^{2}$ Krishi Vigyan Kendra, Sonbhadra, Acharya Narendra Deva University of Agriculture And \\ Technology, Kumarganj, Ayodhya, U.P., India \\ *Corresponding author
}

\section{A B S T R A C T}

\section{Keywords \\ Population dynamics, Tillage systems, Weed diversity indices}

\section{Article Info}

Accepted:

10 July 2020

Available Online:

10 August 2020
The rice-wheat cropping system in the North West IGP is the backbone of food security in India. In the 1990s, due to the scarcity of resources, the traditional Crop Establishment (CE) method shifted from Conventional Till Puddle Transplanted Rice (CTPTR) to CT Direct Seeded Rice (CTDSR) and Zero-Till DSR (ZTDSR) in paddy; and in wheat, from Conventional Till Wheat (CTW) to Zero Till Wheat (ZTW), with residue retention in rice (RRR) or in both rice and wheat (RRRW). Shift in CE methods led to change in Weed Seed Bank (WSB) dynamics and ultimately affected the weed management practices. Review study showed that CTPTR-CTW and ZTDSR-ZTW (RRRW) record the highest seed bank (SB) of grasses, sedges and BLWs as total weeds, in general; and predominant weeds i.e., Echinochloa spp., Ammania baccifera, Commelina benghalensis and Digitaria sanguinalis, in particular. It also showed the higher species richness $\left(\mathrm{D}_{\mathrm{Mg}}\right)$ and Shannon-Weaver $\left(\mathrm{H}^{\prime}\right)$ indices. CTDSRCTW and CTDSR-ZTW (RRR) show the lowest WSB and at par with Shannon-Weaver (H') index; further, lowest species richness $\left(\mathrm{D}_{\mathrm{Mg}}\right)$ under CTDSR-CTW. The average yield losses caused by weeds in different wheat growing zones ranged from 20 to $32 \%$. Uncontrolled weeds in wheat caused $60.5 \%$ reduction in wheat grain yield under CT and $70 \%$ in ZT conditions. Potential solutions include a shift from intensive tillage to no or reduced tillage and/or from transplanting to direct-seeding. Zero tillage ameliorates the problem of delayed sowing as well as reduces weeds like Phalaris minor in wheat. Adoption of conservation agricultural practices reduces the intensity of soil manipulation thereby creates an unfavorable condition for weed seed germination, reduces the organic matter depletion and soil degradation. Reducing tillage may shift weed communities from annual dicots to grassy annuals and perennials. Surface residues lower average soil temperatures and may delay emergence of both crops and weeds. Germination and growth of small-seeded annuals will suffer from restricted light availability, physical growth barriers and potential allelopathic effects from surface of irrigation water, but with an associated yield loss of 14 to $25 \%$. Nevertheless, water use efficiency (WUE) in the residue. Compared with conventional puddled transplanting; direct seeding of rice on raised beds had a 13 to $23 \%$ savings rice wheat system was higher with direct seeded rice $\left(0.45 \mathrm{~g} \mathrm{~L}^{-1)}\right.$ than with transplanted rice $\left(0.37-0.43 \mathrm{~g} \mathrm{~L}^{-1}\right)$. Moreover, CT-TPR system, zero till direct-seeded rice (ZT-DSR) consumed 6\%-10\% less water with almost equal system productivity and demonstrated higher water pro-ductility. 


\section{Introduction}

Seed bank is the source of the above-ground weed community in most cropping systems. The seed bank comprises weed seed recently shed and older seeds that originate from earlier years. In agronomic crop production systems, the soil seed bank (viable p dormant seeds) is the primary source of new infestation of annual weeds in each year, and represents the majority of weed species. Buhler et al., (1997) highlighted that understanding of soil weed seed dynamics is essential to develop improved weed management system. In fact, alteration in crop management practices such as crop rotation and tillage practices influence the viable weed seed density and dynamics by smothering and igniting the emergence of weeds (Dorado et al., 1999).

Weeds are one of the key threats to crop productivity, input-use efficiency and profitability in rice-based cropping systems. Continuous cultivation of rice-wheat cropping sequence favored the intensification of grassy weeds (Bhatt et al., 2016). Tillage systems, crop rotations, choice of crop and management practices affect weed infestation by altering weed seed banks and species composition. Cultivation of crops having similar management practices favors certain weed species to become dominant in the system (Chauhan et al., 2012).

Weed biomass, density, composition and temporal variation are closely associated with management practices, especially tillage (Garcia de Leon et al., 2014; Nichols et al., 2015).

For example, conventional tillage practices may effectively control weeds by burial (Wall, 2008), or stimulate weed germination by raising soil temperature (Murphy et al., 2006). Alternatively, minimal or reduced tillage can shift weed composition from broadleaf to grass species or perennial weeds or increase weed species diversity when specific habitats for certain weeds are created (Murphy et al., 2006). Mulch or soil cover may reduce or inhibit weed germination through the release of allelopathic compounds or smothering of weeds (Thierfelder and Wall, 2010). Furthermore, weeds can be influenced by location, time, nitrogen management, timing of cultivation, rainfall, crop residue management, crop rotations, harvest procedures and other aspects of the production system (Wall, 2008).

Changes in tillage regime may cause floristic inversion due to changes in the seed-bank (Ball, 1992). Incorporating seeds deeper into the soil with tillage might favor conditions for an increase of seed-bank (Buhler et al., 1997), but burying seeds might also avoid seed germination (Chauhan et al., 2006) and favor seed deterioration (Gomez et al., 2013). Under no-till and RTF, seeds are more likely to remain near the soil surface where they are susceptible to insect and bird predation in the summer periods (Baraibar et al., 2017). Germination of some species is favored when seeds are near the soil surface and thus no-till and RTF will increase seedling emergence compared with conventional tillage. However, Mohler, (1993) observed that emergence increased in the first year followed by reduction in later years due to depletion of the seed surface fraction by the action of herbicides and shallow cultivation.

Moreover, crop residues associated with notill and RTF may suppress weeds by blocking sunlight and reducing physical space for seedling emergence (Fernandez et al., 2008). This paper reviews the crop establishment with tillage practices on weed seed density and diversity and productivity in rice-wheat rotation. 


\section{Crop Establishment Methods}

Chauhan et al., (2015) reported that grass weeds were higher in dry-seeded rice compared to puddled transplanted rice (PTR) and nonpuddled transplanted rice. The highest total weed density (225-256 plants $\mathrm{m}^{-2}$ ) and total weed biomass $\left(315-501 \mathrm{~g} \mathrm{~m}^{-2}\right)$ were recorded in dry-seeded rice, while the lowest (102-129 plants $\mathrm{m}^{-2}$ and $75-387 \mathrm{~g} \mathrm{~m}^{-2}$ ) in PTR. Chhokar et al., (2014) also found the highest yield and least weed abundance in the PTR. Compared to the transplanting rice, severe weed infestation was found in the dry and wet DSR and thus lesser yield was found in DSR compared to transplanting rice both in the presence and absence of weeds. The yield losses due to weeds in the DSR treatments ranged from 91.4 to $99.0 \%$, compared to 16.0 and $42.0 \%$ in the transplanting treatments. Weeds, including C.rotundus, $D$. aegyptium, Digera arvensis Forsk., Phyllanthus niruri L., and T. portulacastrum, which were present in the unpuddled DSR treatments, were not found in the puddled plots, particularly the puddled transplanting treatments. When rice residues are kept on soil surface as mulch, reduced weed emergence of key weeds of wheat in the range of 45-99\%, depending on species and mulch amount. Emergence of $P$. minor, Chenopodium album, and $R$. dentatus was inhibited by 45,83 and $88 \%$, respectively at 6 t/ha rice residue load com-pared to without residue mulch (Kumar et al., 2013).

Sharma et al.(2020) also found that CTDSRCTW recorded the lowest Shannon-Weaver $(\mathrm{H})$ and Species richness $\left(\mathrm{D}_{\mathrm{Mg}}\right)$ while the highest in CTPTR-CTW, statistically at par with CTDSR-ZTW (RRR) and ZTDSR-ZTW (RRRW). Conversely, the highest $\beta_{\mathrm{W}}$ was observed under the CTDSR-CTW and the lowest in CTPTR-CTW which is at par with CTDSR-ZTW (RRR) and ZTDSR-ZTW (RRRW). Change in the crop establishment methods alters the soil ecology, while affecting the soil nutrient, soil structure and temperature, as well as the depth of burial of weed seeds, which ultimately affects the germination of weed species and its composition (Plaza et al., 2011). In fact, level of soil disturbance affects the weed species richness, abundance and density of weeds (Lal et al., 2016). Species diversity within weed communities and the nature of their relationship are of agronomic importance. However, weed categories and their species, maximum WSB observed at the top 0-10 cm, which gradually reduced with depth. Likewise, weed diversity indices, except $\beta_{\mathrm{W}}$, also record the similar trend. Higher species richness and Shannon-Weaver index in top $0-10 \mathrm{~cm}$ indicate more diverse number of weed species exists; further, higher Simpson index in $0-10$ and $10-20 \mathrm{~cm}$ soil depth signifies the dominance of some of the species in the upper layer as compared to the lower depth.

Nandan et al., (2020) observed that the extent of weed seed emergence differed $\left(0.7-29 \mathrm{~m}^{2}\right.$ in 2013-14 and 0.7-27 in 2014-15) among treatments. Density was the lowest for Sonchus oleraceous L., Anagalis arvensis L., Phyllathus niruri L., and the highest for Cyperus iria L. The total weed seed emergence was higher in rice-wheat rotation over rice-maize system (Fig. 1).On average, treatment receiving crop residue had the higher seed density over no-residue application. The total weed seed density in ZTTPR-ZT, UPTPR-ZT, and CTTPR-CT did not differ, however, they significantly recorded 4.8, 4.1, and 3.4\% higher emergence (mean of two years) over ZTDSR-ZT, respectively (Fig. 1).However, in rice-maize system recorded the significantly higher Oxalis corniculata L. emergence over ricewheat system by $64 \%$, whereas, with residue treatment recorded $32 \%$ higher $O$. corniculata emergence over without residue addition (Fig. 
2). The UPTPR-ZT, ZTTPR-ZT, and ZTDSR-ZT systems recorded the lower O. corniculata seed density by 37,62 , and $61 \%$, respectively, over the CTTPR-CT. However, CTTPR-CT system had higher Chenopodium album L. and Rumex dentatus L. emergence over the other practices (Fig. 2). Among tillage practices, ZTTPR-ZT and UPTPR-ZT recorded higher $S$. nigrum emergence over CTTPR-CT.

\section{Viability of weed seeds}

Tillage-induced changes in seed distribution will also have implications for seed viability. Burial increases seed survival while seeds on or close to the soil surface can lose viability due to desiccation and harsh weather (Anderson, 2005).Therefore, depending on the extremity of the environment, the accumulation of seeds on un-tilled soil surfaces may increase the proportion of unviable weed seeds in the seed-bank. Seed dispersal and recruitment may be affected by tillage practice. Field traffic and machinery operations such as tillage provide opportunities to introduce or spread weed seeds (Buhler et al., 1997). One study showed cultivation following harvest significantly increased weed seed dispersal (Heijting et al., 2009), and another found the weed seeds travelled 2-3 $\mathrm{m}$ in the direction of tillage, while in un-tilled soils the distance was negligible (Barroso et al., 2006). Reducing tillage can therefore reduce the spread of weed seed both within and across fields.

Chhokar et al., (2007) reported that Rumex dentatus was significantly higher (12.1 plants $/ \mathrm{m}^{2}$ ) under zero tillage (ZT) compared to conventional tillage (CT) (1.9plants $\left./ \mathrm{m}^{2}\right)$. CT favored Phalaris minor. The average P. minor dry weight under ZT and CT was 234.7 and $386.5 \mathrm{~g} / \mathrm{m}^{2}$, respectively. This differential response reflected was due to variation in seed distribution during puddling performed for rice transplanting. Swanepoe et al., (2015) reported that a temporal variation can be expected; with an increase in weed biomass under RT practices, while under CT practices weed biomass was more stable over cultivation time. Similarly, we detected a temporal trend in weed species diversity, where species diversity increased under RT but decreased under CT. Following this trend we would expect a time effect on species composition, with higher diversity the longer the trial continues. Indeed species diversity suggests that RT had higher species diversity than CT. CT also had a low Evenness index (E), which suggests that CT is dominated by a few weed species, but that these species occurs in high abundance, while RT had a lower $\mathrm{E}$ value and hence higher diversity, but at lower abundances. Furthermore, the temporal variation in weed biomass under different tillage practices concurs with Swanton et al., (1999) who reported that weed biomass varied between tillage practice and cultivation year.

In conventionally tilled soils, this can be explained by the increase in environmental variables, such as temperature and moisture, as a result of tillage. Increased environmental variables could lead to more favorable conditions in certain years, and this in turn could lead to a large year-to-year variation in weed density. Changing tillage regimes changes the disturbance frequency of the farm field, which results in a shift in weed species (Boscutti et al., 2015). As NT can favor certain granivore species over others, the associated shift in preferred seed consumption may contribute to altered seed-bank composition (Brust and House, 1988). While there is consensus that the weed species composition will shift in response to changes in tillage, whether the diversity of the weed community increases is less clear. Ecologically, highly disturbed environments will tend to be simpler than more stable ones. 
Compared to tilled soils, higher weed species diversity has been observed in NT seed-banks (Sosnoskie et al., 2006) emerged weed communities or both (Murphy et al., 2006). Studies that report no increase in diversity with NT all found either crop rotation or weather had a larger effect on weed species diversity. While tillage will contribute to community shifts, the weed species present will be an expression of both management and the environment, which in many cases may be simply the weather (Boscutti et al., 2015).

Nandan et al., (2020) also found that weed species belonging to different botanical families were emerged (Tables 1). Of the total 33 weed species, 15 species were present abundantly in all treatments. The extent of weed seed emergence differed $\left(0.7-29 \mathrm{~m}^{-2}\right)$ among treatments. Density was the lowest for Sonchus oleraceous L., Anagalis arvensis L., Phyllathus niruri L., and the highest for Cyperus iria L. Furthermore, CTTPR-CT to UPTPR-ZT and ZTDSR-ZT systems in ricemaize and rice-wheat systems significantly influenced the weed seed density and diversity. Fifteen weed species were abundantly present, and 5 species were in high frequency in all the treatments out of total 33 weed species in the seed-bank.

It indicated that manipulation in crop management practices can alter the abundance of weed species. Moreover, $C$. iria, $P$. minima, O. corniculata, $C$. album, and $B$. diffusa were present in huge density in all the treatments. Hence, these weed species in seed-bank can be the most dominant weed flora in these ecologies in future. The soil micro climate was not favorable for their germination in the field or low sensitivity of these weeds to the cropping systems and tillage techniques kept these weeds dormant in field (Nandan et al., 2018a).
Barberi and Lo Cascio, (2001) reported that the reduction in weed density occurs if the weed seed bank depletion is greater than weed seed shedding. However, this situation is rarely achieved with no-tillage. Therefore, weed densities in no-tillage systems are generally higher than in plough-based systems. Moreover, the findings of a longterm experiment with four tillage systems (Fig. 3a) adopted for 12 consecutive years in a continuous winter wheat or a pigeon beanwinter wheat rotation showed that total weed seedling density in ZT, minimum tillage using rotary harrow (15 cm depth), and chisel ploughing (45 cm depth) was relatively higher in the $0-15,15-30$, and $30-45 \mathrm{~cm}$ soil layers, respectively. Mulugeta and Stoltenberg (1997) noticed a several-fold increase in weed seedling emergence due to tillage. The impact of tillage vis-à-vis weed infestation in the crop field is influenced by the previous cropping systems. Continuous ZT increased the population density of awn-less barnyard grass and rice flats edge in rice, but rotational tillage systems significantly reduced the seed density of these weeds.

Chauhan and Abugho (2012) reported that $6 \mathrm{t}$ $\mathrm{ha}^{-1}$ crop residues reduced the emergence of jungle rice, crowfoot grass and rice flat sedge by $80-95 \%$ but only reduce the emergence of barnyard grass by up to $35 \%$ (Fig. 3b). The effectiveness of crop residue to reduce weed emergence also depends upon the nature of weed species to be controlled.

\section{Weed flora and density}

Weed flora of wheat differ from field to field, depending on environmental conditions, irrigation, fertilizer use, soil type, weed control practices and cropping sequences. The predominant weeds associated with conventional till wheat are Phalaris minor, Poa annua, Polypogon monspeliensis, Avena ludoviciana, Rumex dentatus, $R$. spinosus, 
Anagallis arvensis, Convolvulus arvensis, Malva parviflora, Medicago denticulata, Chenopodium album, Vicia sativa, Lathyrus aphaca, Circium arvense, Melilotus alba, Coronopus didymus, Polygonum plebejum and Spergula arvensis. Among grassy weeds, $P$. minor and among broad-leaved weeds, Rumex dentatus and Medicago denticulata are of major concern in irrigated wheat under rice-wheat system in India (Chhokar et al., 2006). Phalaris minor is major problem in heavy soils, whereas, wild oat is more prevalent in light textured soil under non ricewheat rotation. Both $P$. minor and $R$. dentatus are highly competitive weeds and can cause drastic yield reduction under heavy infestation. Evolution of resistance in $P$. minor (Chhokar and Sharma, 2008) against isoproturon has made it a single weed species limiting wheat productivity in the NorthWestern plains of India.

Tillage can influence the vertical weed seed distribution in the soil profile, soil moisture, diurnal temperature fluctuations, light availability, and activities of seed predators and microbes. All these factors can affect weed recruitment in the field by influencing seed dormancy, emergence, and seed mortality. Reduced tillage favoured the growth of Cirsium arvense and Convolvulus arvensis (Catizone et al., 1990). ZT wheat lowers the $P$. minor infestation, which is the main threat to the sustainability of wheat production under rice-wheat system (Franke et al., 2007). Yadav and Singh (2005) observed that maximum $P$. minor population emerged from 0-3 cm soil depth. In both CT and ZT wheat, after direct seeded unpuddled and puddled rice, there was no emergence of $P$. minor from 6-9 $\mathrm{cm}$ depth but still 5\% population could emerge from this layer after transplanted rice. Under CT wheat, there was $16 \%$ increase in $P$. minor density during 15 to 20 days after sowing in the field before irrigation, but after first irrigation the density of this weed increased by $175 \%$ during 20 to 40 days after sowing. In ZT wheat, the density of this weeds increased by $61 \%$ before irrigation and after irrigation this increase was only $102 \%$.

Radhey Shyam et al., (2009) reported that wheat sown with CT led to significantly higher density of $P$. minor, $M$. indica, $M$. denticulata and $C$. album as compared to ZT sown crop. Contrary to this, weed seeds remained in sub-surface under zero till sown crop due to puddling carried out during paddy transplanting and failed to germinate because of unfavorable conditions (Sinha and Singh, 2005). Mishra and Singh (2012) showed a strong propensity to increase under all the tillage systems (ZT and CT in rice and wheat continuous and alternated) indicating its ability to persist under modern cropping systems. But in subsequent years, continuous zero tillage lowered its population. Chenopodium album seedling emergence declined significantly due to ZT wheat sowing during first year; in subsequent years, population of $C$. album was completely eliminated due the increased density of $A$. ludoviciana and $M$. hispida in all the tillage systems.

\section{Weed seed bank and its dynamics in soil}

Weed seed bank is the natural storage of various weed seeds at different depths in soil. The seed bank in the soil builds up through seed production and dispersal, while it depletes through germination, predation and decay. The distribution of weed seeds within the soil profile is mainly influenced by different types of tillage practices. Repeated tillage reduces the number of weed propagules in the plough layer. Weed seed burial by tillage is difficult or negligible in case of conservation tillage than in conventional tillage. No-tillage system leaves most of the weed seeds in the top one $\mathrm{cm}$ of 
soil profile, whereas mouldboard ploughing tends to uniformly distribute seeds throughout the profile, and chisel ploughing and other reduced tillage systems are intermediate in differential distribution of seeds in the soil profile. Redistribution of seeds in soil profile is stimulated by tillage practices which favor germination. In the ZT system, the weed seed bank remains on or close to the soil surface after cropplanting (Chauhan et al., 2006). Better tilth and exposure of the weed seeds to upper soil may be responsible for higher weed infestation under conventional tillage than ZT. Seeds of some species like $R$. dentatus are sensitive to burial depth, which could not emerge at a burial depth of $4 \mathrm{~cm}$ (Dhawan, 2005). Weed species like Digitaria ciliaris does not emerge from a seed burial depth of 6 $\mathrm{cm}$ (Chauhan and Johnson, 2008). Though most of the weed seedlings emerge from top 0.5 to $2 \mathrm{~cm}$ depth of soil layer, some weeds species like Mimosa invisa and E. crusgalli can emerge from a burial depth of $8 \mathrm{~cm}$ (Chauhan and Johnson, 2010). ZT systems may reduce the emergence of seedlings of some weed species, as seeds at the soil surface are prone to rapid desiccation. Tillage has also been found to influence vertical seed distribution and seed bank dynamics, resulting in higher weed pressure in ZT systems due to presence of weeds in uppermost soil layer (Singh et al., 2015). Differential vertical distribution of seeds in soil has the potential to affect seedling emergence and weed population dynamics, as soil depths differ in availability of moisture, diurnal temperature fluctuation, light exposure and activity of predators. For determination of seed depth and seed germination, seed burial and excavation by tillage is main factor. However, tillage is not solely responsible for seed burial at different depths, but natural processes also play significant role in partial burial. Seed densities of $P$. minor, Melilotus indica and $C$. album in soil were significantly lower under
ZT as compared to conventional tillage from 0 to 5,5 to 10 and 10 to $15 \mathrm{~cm}$ soil depths, respectively, whereas, seed density of Rumex acetosella in soil was found higher in case of ZT than others, but differences were significant only at $5-10 \mathrm{~cm}$ of soil depth (Shyam et al., 2014).

Arif et al., (2007) in maize noted that the major were Cyperus rotundus, Cynodon dactylon,Chenopodium album, Echinochloa crus-galli and Cucumis prophetarum and were sorted into groups according to their life cycle. Annual weeds did not show dependable response to tillage system eccept E. colonum which decreased with increase in tillage intensity. These results agree with Bostrom and Fogelforsm (1999) who reported that soil disturbance has limited influence on the summer annual weeds. Among the perennial weeds, the density of $C$. dactylon decreased with increase in tillage intensity while $C$. rotundus showed inconsistent response to tillage intensity.

Brar and Walia, (2007) also found that infesting wheat fields and of theses, Phalaris minor, polypogan monspeliensis, Poa апnua, Rumex dentatus, Medicago denticulate, Anagallis arvensis and Malva nelgecta were most common. Slightly higher population of broadleaf weeds was observed in zero tillage as compare to the conventional methods while adverse trend was seen in case of broadleaf weeds

Punia et al., (2016) reported that in rice $E$. colona, L. chinensis, $E$. crusgalli, $C$. difformis, A. baccifera and Dactyloctenium aegyptium were the major weeds emerged from soil at different soil depths. Number of weed seeds emerged was more in ZT-ZT and MT-ZT treatments as compared to CT-CT. Weed density was maximum in upper $0-5 \mathrm{~cm}$ soil layer in all treatments. Moreover, from different soil depths under different 
treatments before wheat sowing revealed predominance of $P$. minor, $C$. album and $M$. indica in all treatments. Density of weeds was maximum in CT-CT treatment and it was distributed in all soil depths being more in 0-5 and 5- $10 \mathrm{~cm}$ soil depths. In ZT-ZT and CTZT (rice-wheat) treatments, density of weeds was minimum and that was mainly concentrated in 0-5 and 5-10 cm soil depth. $P$. minor population was very low in ZT-ZT or CT-ZT treatments as compared to CT-CT in 0-5 $\mathrm{cm}$ and 5-10 $\mathrm{cm}$ soil depth. Density of broad-leaf weeds particularly $C$. album was more in CT-ZT treatment followed by ZT-ZT and MT-ZT treatments at both soil depths.

Sharma et al., (2020) reported that the vertical distribution of SB of grasses, sedges, BLW, and total weeds had been affected by the different CE methods (Fig. 4a). In CTPTRCTW, there was almost a uniform distribution of the grasses, BLWs, and total weeds, while the sedges SB observed significant reduction
(14.29\%) in the 20-30 cm layer. In CTDSRCTW, the top layer $(0-10 \mathrm{~cm})$ contained about half of the total WSB (47-59\%) and thereafter gradual decrease in the WSB with respect to the depth, except sedges in which there was an abrupt decrease in SB with depth i.e., from 73.33 per cent in $0-10 \mathrm{~cm}$ to 6.67 per cent in 20-30 cm. Furthermore, in CTDSR-ZTW (RRR) and ZTDSR-ZTW (RRRW) methods, SB of most of grasses (68$72 \%)$, BLWs (68-82\%), and total weeds (65$76 \%$ ) was confined to the upper layer of the soil profile $(0-10 \mathrm{~cm})$. The bottom layer $(20-$ $30 \mathrm{~cm}$ ) consisted of the minimum grassy weeds (9-14\%), BLWs density (5\%) and total weeds (7-9\%). Conversely, the top layer of soil profile $(0-10 \mathrm{~cm})$ consisted of about 54$59 \%$ sedges $\mathrm{SB}$, while the subsequent layers, i.e., $10-20 \mathrm{~cm}$ and $20-30 \mathrm{~cm}$ consisted of $31-$ $35 \%$ and $5-6 \%$ of sedges density in both the ZT systems (CTDSR-ZTW (RRR) and ZTDSR-ZTW (RRRW).

Table.1 Effect of cropping systems, residue management, and tillage techniques on total seed density (no. $\mathrm{m}^{-2}$ ) of individual weed

\begin{tabular}{|c|c|c|c|c|c|c|c|c|}
\hline \multirow[t]{2}{*}{ Weed species } & \multicolumn{2}{|c|}{ Cropping system ${ }^{*}$} & \multicolumn{2}{|c|}{ Residue management } & \multicolumn{4}{|c|}{ Tillage techniques } \\
\hline & Rice-wheat & Rice-maize & Without residue & With residue & CTTPR-CT & UPTPR-ZT & ZTTPR-ZT & ZTDSR-ZT \\
\hline Echinochloa colona $\mathrm{L}$. & $11.2 \pm 1.5$ & $7.9 \pm 0.9$ & $11.5 \pm 1.0$ & $7.7 \pm 1.5$ & $13.0 \pm 0.8$ & $8.5 \pm 1.5$ & $9.2 \pm 2.5$ & $7.6 \pm 0.9$ \\
\hline Leptochloa chinensis $\mathrm{L}$. & $0.71 \pm 0.0$ & $1.34 \pm 0.6$ & $1.34 \pm 0.7$ & $0.71 \pm 0.0$ & $0.71 \pm 0.0$ & $0.71 \pm 0.0$ & $1.34 \pm 0.7$ & $1.34 \pm 0.7$ \\
\hline Cyperus iria $\mathrm{L}$. & $27.5 \pm 1.3$ & $24.6 \pm 2.0$ & $26.0 \pm 2.1$ & $26.1 \pm 1.0$ & $29.2 \pm 3.6$ & $20.8 \pm 0.8$ & $25.6 \pm 3.3$ & $28.6 \pm 2.8$ \\
\hline Cyperus rotundus $\mathrm{L}$. & $4.21 \pm 1.5$ & $2.67 \pm 0.9$ & $4.07 \pm 0.6$ & $2.81 \pm 0.3$ & $2.81 \pm 1.3$ & $4.91 \pm 0.4$ & $1.96 \pm 0.6$ & $4.07 \pm 1.1$ \\
\hline Caesulia axillaris Roxb. & $9.6 \pm 0.9$ & $7.2 \pm 1.4$ & $7.9 \pm 1.3$ & $8.9 \pm 0.3$ & $13.2 \pm 2.1$ & $8.1 \pm 1.0$ & $2.9 \pm 1.1$ & $9.4 \pm 0.7$ \\
\hline Alternanthera philoxiroides Griseb. & $10.1 \pm 1.1$ & $15.6 \pm 2.6$ & $12.5 \pm 2.9$ & $13.1 \pm 2.0$ & $8.6 \pm 1.6$ & $13.5 \pm 1.5$ & $18.0 \pm 3.2$ & $11.2 \pm 2.7$ \\
\hline Euphorbia hirta L. & $4.6 \pm 0.9$ & $6.5 \pm 0.8$ & $6.0 \pm 0.3$ & $5.1 \pm 1.9$ & $1.3 \pm 0.6$ & $8.6 \pm 2.8$ & $8.8 \pm 0.6$ & $3.4 \pm 1.4$ \\
\hline Physalis minima $\mathrm{L}$. & $22.2 \pm 3.9$ & $9.0 \pm 2.3$ & $14.8 \pm 2.9$ & $16.4 \pm 3.2$ & $13.1 \pm 2.6$ & $22.0 \pm 5.4$ & $16.1 \pm 4.4$ & $11.2 \pm 1.5$ \\
\hline Amaranthus viridis $\mathrm{L}$. & $3.16 \pm 0.9$ & $5.71 \pm 1.6$ & $3.55 \pm 1.4$ & $5.32 \pm 0.9$ & $4.85 \pm 2.1$ & $2.87 \pm 1.3$ & $6.50 \pm 0.9$ & $3.50 \pm 1.6$ \\
\hline Portulaca oleracea $\mathrm{L}$. & $3.93 \pm 0.3$ & $2.78 \pm 0.6$ & $3.55 \pm 0.9$ & $3.16 \pm 1.1$ & $3.09 \pm 0.5$ & $0.71 \pm 0.0$ & $6.74 \pm 1.5$ & $2.87 \pm 1.3$ \\
\hline Trianthema portulacastrum $\mathrm{L}$. & $3.99 \pm 0.7$ & $6.03 \pm 1.8$ & $4.45 \pm 0.8$ & $5.57 \pm 1.6$ & $5.61 \pm 2.1$ & $3.85 \pm 0.6$ & $6.17 \pm 0.4$ & $4.41 \pm 0.5$ \\
\hline Cyanotis axillaris $\mathrm{L}$. & $1.02 \pm 0.3$ & $1.48 \pm 0.7$ & $1.48 \pm 0.7$ & $1.02 \pm 0.3$ & $0.71 \pm 0.0$ & $0.71 \pm 0.0$ & $2.25 \pm 0.8$ & $1.34 \pm 0.6$ \\
\hline Ageratum conyzoides $\mathrm{L}$. & $2.07 \pm 0.6$ & $2.42 \pm 0.2$ & $2.42 \pm 0.8$ & $2.07 \pm 0.4$ & $1.34 \pm 0.6$ & $3.73 \pm 1.0$ & $2.59 \pm 1.8$ & $1.34 \pm 0.6$ \\
\hline Eclipta prostrata $\mathrm{L}$. & $4.49 \pm 1.8$ & $4.90 \pm 2.2$ & $3.39 \pm 1.6$ & $6.01 \pm 2.3$ & $5.94 \pm 1.5$ & $3.37 \pm 1.3$ & $6.38 \pm 2.0$ & $3.09 \pm 1.5$ \\
\hline Ammania baccifera $\mathrm{L}$ & $4.47 \pm 1.4$ & $3.01 \pm 1.3$ & $4.01 \pm 2.4$ & $3.47 \pm 1.3$ & $4.80 \pm 1.2$ & $3.50 \pm 1.4$ & $3.22 \pm 1.5$ & $3.44 \pm 1.7$ \\
\hline Ludwigia hyssoypifolia G. Don & $6.49 \pm 1.9$ & $4.07 \pm 2.4$ & $3.98 \pm 1.7$ & $6.58 \pm 2.1$ & $2.46 \pm 1.7$ & $3.72 \pm 1.1$ & $6.52 \pm 2.1$ & $8.42 \pm 2.2$ \\
\hline Corchorus olitorius $\mathrm{L}$. & $1.73 \pm 0.8$ & $0.71 \pm 0.0$ & $1.16 \pm 0.4$ & $1.27 \pm 0.5$ & $0.71 \pm 0.0$ & $1.62 \pm 0.9$ & $1.84 \pm 1.1$ & $0.71 \pm 0.0$ \\
\hline Oldenlandia corymbosa $\mathrm{L}$. & $9.8 \pm 2.8$ & $9.4 \pm 2.3$ & $9.3 \pm 2.5$ & $9.9 \pm 2.6$ & $10.1 \pm 3.0$ & $8.6 \pm 2.9$ & $9.2 \pm 2.2$ & $10.6 \pm 3.6$ \\
\hline Phyllanthus niruri L. & $1.34 \pm 0.3$ & $0.71 \pm 0.0$ & $0.71 \pm 0.0$ & $1.34 \pm 0.3$ & $0.71 \pm 0.0$ & $0.71 \pm 0.0$ & $0.71 \pm 0.0$ & $1.96 \pm 0.6$ \\
\hline Boerhavia diffusa $\mathrm{L}$. & $20.8 \pm 2.6$ & $14.1 \pm 6.4$ & $14.9 \pm 0.7$ & $20.0 \pm 2.1$ & $14.7 \pm 2.8$ & $18.9 \pm 1.9$ & $16.1 \pm 0.5$ & $20.2 \pm 1.3$ \\
\hline Melilotus indicus L. & $5.01 \pm 1.2$ & $1.65 \pm 0.5$ & $2.28 \pm 1.1$ & $4.38 \pm 0.4$ & $4.13 \pm 1.5$ & $3.09 \pm 1.5$ & $2.87 \pm 2.1$ & $3.22 \pm 0.6$ \\
\hline Achyanthes aspera $\mathrm{L}$. & $2.95 \pm 1.2$ & $1.16 \pm 0.4$ & $2.32 \pm 1.2$ & $1.79 \pm 0.5$ & $2.81 \pm 1.1$ & $2.75 \pm 0.2$ & $1.34 \pm 0.6$ & $1.34 \pm 0.6$ \\
\hline Rumex dentatus $\mathrm{L}$. & $9.4 \pm 1.3$ & $7.8 \pm 2.0$ & $7.9 \pm 1.9$ & $9.4 \pm 2.6$ & $8.5 \pm 2.2$ & $10.5 \pm 1.3$ & $10.0 \pm 0.7$ & $5.5 \pm 1.1$ \\
\hline Sonchus oleraceous $\mathrm{L}$. & $1.34 \pm 0.6$ & $0.71 \pm 0.0$ & $1.02 \pm 0.3$ & $1.02 \pm 0.3$ & $0.71 \pm 0.0$ & $0.71 \pm 0.0$ & $0.71 \pm 0.0$ & $1.96 \pm 1.2$ \\
\hline Oxalis corniculata $\mathrm{L}$. & $18.0 \pm 2.5$ & $15.9 \pm 2.9$ & $17.1 \pm 2.2$ & $16.7 \pm 3.2$ & $21.4 \pm 3.1$ & $18.4 \pm 1.5$ & $12.8 \pm 1.3$ & $15.1 \pm 2.1$ \\
\hline Medicago denticulata $\mathrm{L}$. & $6.1 \pm 2.1$ & $7.0 \pm 2.8$ & $7.8 \pm 2.7$ & $5.3 \pm 2.3$ & $6.1 \pm 1.6$ & $6.6 \pm 2.1$ & $7.8 \pm 2.8$ & $5.7 \pm 1.5$ \\
\hline Chenopodium album $\mathrm{L}$. & $14.1 \pm 2.6$ & $28.0 \pm 1.9$ & $22.9 \pm 1.9$ & $19.3 \pm 3.2$ & $24.5 \pm 3.5$ & $23.2 \pm 2.0$ & $19.0 \pm 3.8$ & $17.8 \pm 3.4$ \\
\hline Coronopus didymus Zinn & $6.4 \pm 2.7$ & $6.2 \pm 1.2$ & $6.7 \pm 2.4$ & $5.9 \pm 1.9$ & $4.2 \pm 1.6$ & $7.6 \pm 2.2$ & $6.7 \pm 2.7$ & $6.7 \pm 2.4$ \\
\hline Solanum nigrum L. & $6.4 \pm 2.0$ & $9.6 \pm 1.2$ & $8.3 \pm 1.0$ & $7.7 \pm 0.9$ & $5.8 \pm 2.0$ & $9.4 \pm 1.2$ & $7.1 \pm 1.9$ & $9.7 \pm 2.6$ \\
\hline Anagalis arvensis $\mathrm{L}$. & $1.27 \pm 0.5$ & $0.71 \pm 0.0$ & $1.27 \pm 0.5$ & $0.71 \pm 0.0$ & $0.71 \pm 0.0$ & $0.71 \pm 0.0$ & $0.71 \pm 0.0$ & $1.84 \pm 1.0$ \\
\hline Circium arvense $\mathrm{L}$. & $1.02 \pm 0.3$ & $1.96 \pm 0.4$ & $1.65 \pm 0.5$ & $1.34 \pm 0.3$ & $2.59 \pm 1.0$ & $1.34 \pm 0.6$ & $0.71 \pm 0.0$ & $1.34 \pm 0.6$ \\
\hline Vicia sativa $\mathrm{L}$. & $0.71 \pm 0.0$ & $0.71 \pm 0.0$ & $0.71 \pm 0.0$ & $0.71 \pm 0.0$ & $0.71 \pm 0.0$ & $0.71 \pm 0.0$ & $0.71 \pm 0.0$ & $0.71 \pm 0.0$ \\
\hline
\end{tabular}

Data were subjected to square square-root $(\sqrt{(x+0.5)})$ transformation. Mean values of cropping systems are averaged over residue and tillage treatments. Values are expressed as mean \pm standard error of mean. 
Fig.1 Effect of different management practices on total viable seed density (no. $\mathrm{m}^{-2}$ ) in soil
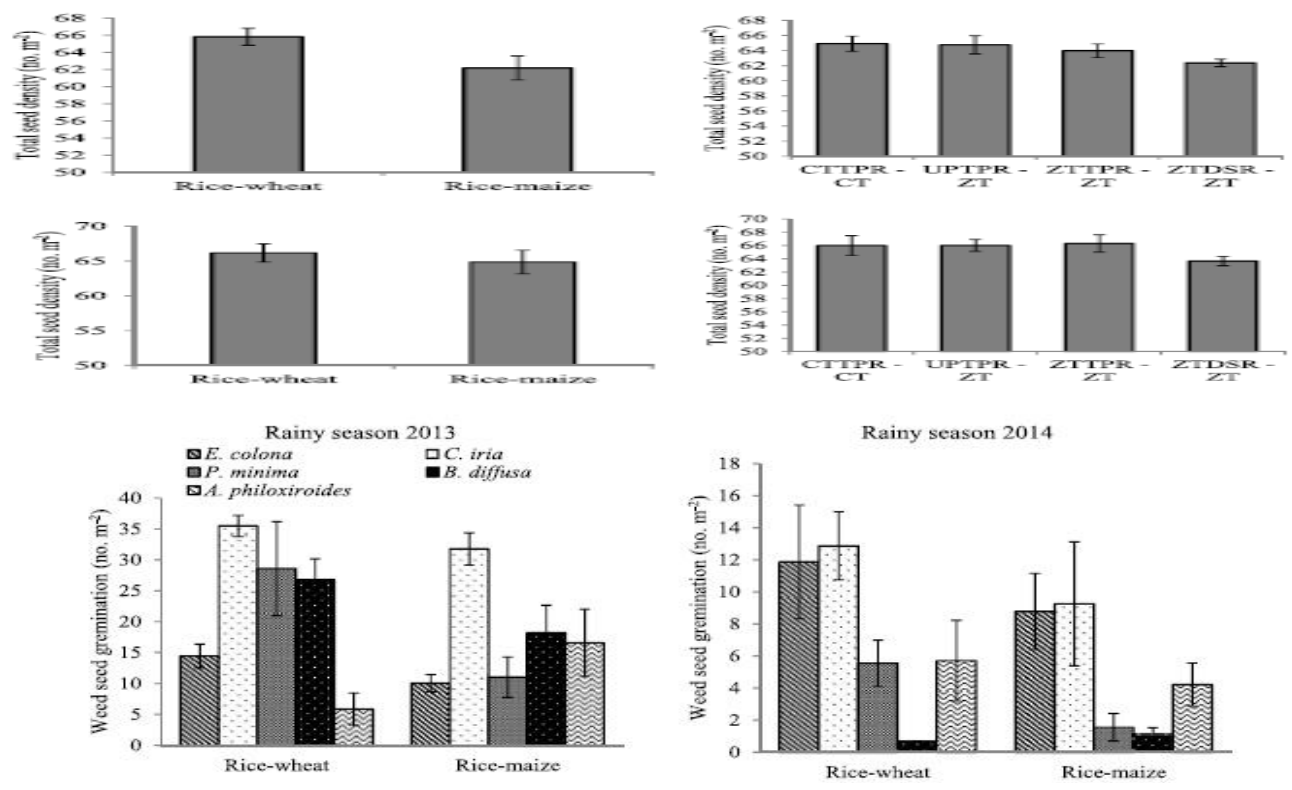

Fig.2 Emergence pattern of major rainy season weeds (no. $\mathrm{m}^{-2}$ ) under cropping system and tillage techniques
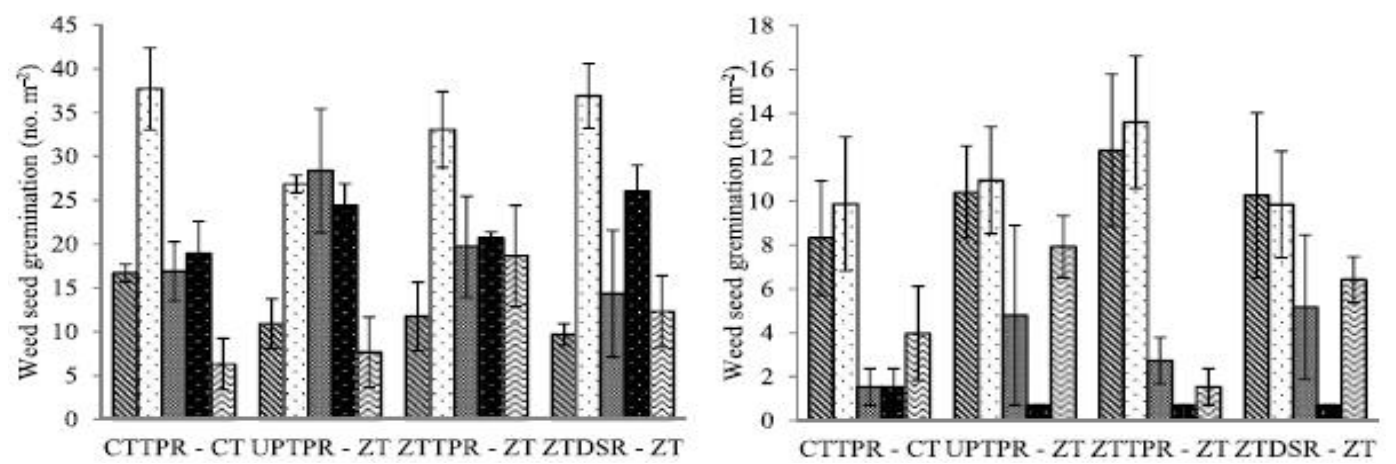

Fig.3a Percent weed seedling distribution over soil layers in mould board ploughing at $45 \mathrm{~cm}$ depth (P 45), chisel ploughing at $45 \mathrm{~cm}$ depth (CP 45), rotary harrowing at $15 \mathrm{~cm}$ depth (RH 15), and zero-tillage $(\mathrm{ZT})$

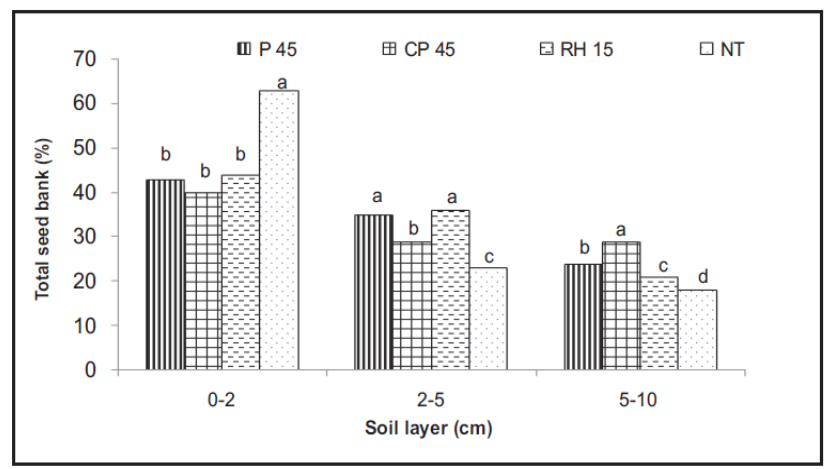


Fig.3b The effect of rice residues on weed germination (Chauhan and Abugho 2012)

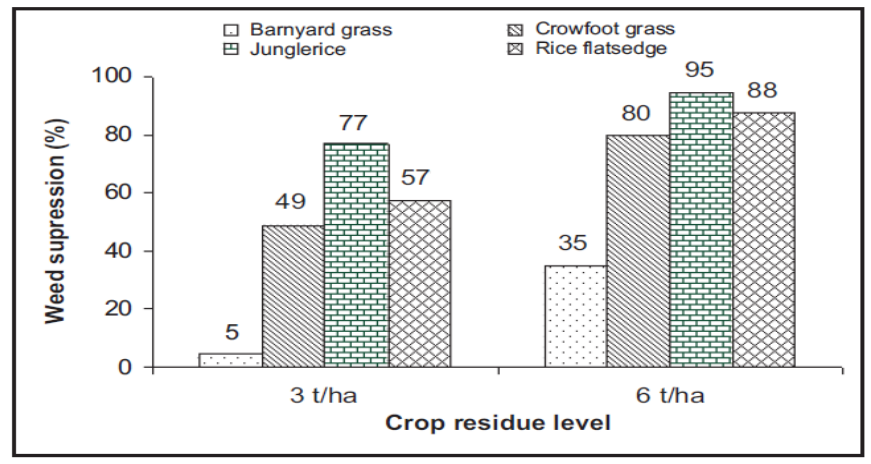

Fig.4a Vertical distribution of grasses, sedges and broadleaved weeds (BLWs) in different crop establishment methods of rice-wheat cropping system

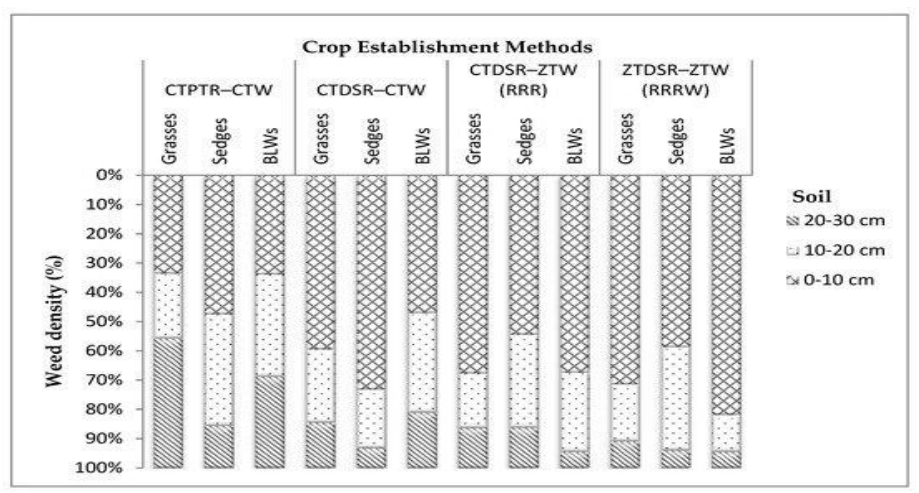

Fig.4b The effect of tillage systems on the vertical distribution of weed seeds

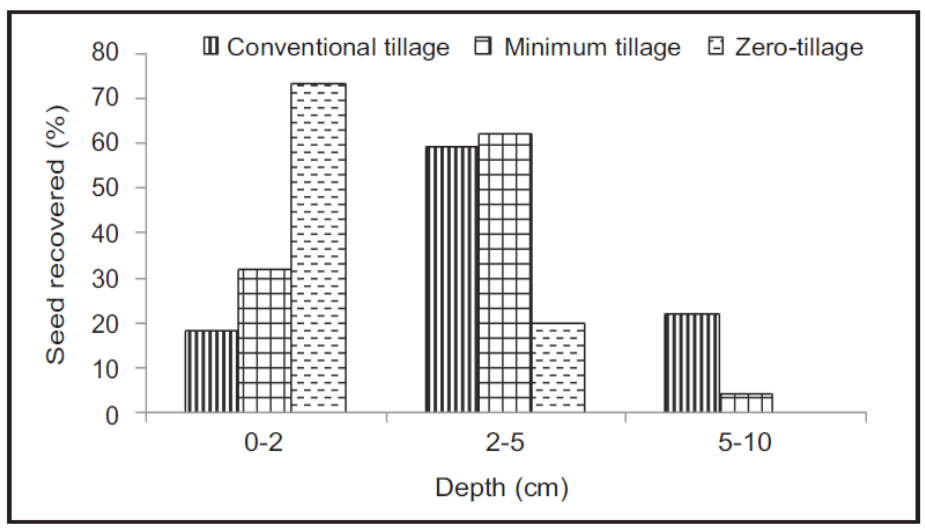

The seed bank consists of new seeds recently shed by weed plants as well as older seeds that have persisted in the soil for several years. The seed bank builds up through seed production and dispersal, while it depletes through germination, predation and decay.
Different tillage systems disturb the vertical distribution of weed seeds in the soil, in different ways. The success of the CA system depends largely on a good understanding of the dynamics of the weed seed bank in the soil. Under ZT, there is little opportunity for 
the freshly-rained weed seeds to move downwards in the soil and hence remains mostly on the surface, with the highest concentration in the $0-2 \mathrm{~cm}$ soil layer, and no fresh weed seed is observed below $5 \mathrm{~cm}$ soil depth (Fig. 4b). Under conventional and minimum tillage systems, weeds seeds are distributed throughout the tillage layer with the highest concentration of weed seeds in the $2-5 \mathrm{~cm}$ soil layer. Mouldboard ploughing buries most weed seeds in the tillage layer, whereas chisel ploughing leaves the weed seeds closer to the soil surface. Similarly, depending on the soil type, 60-90\% of weed seeds are located in the top $5 \mathrm{~cm}$ of the soil in reduced or no-till systems (Chauhan and Johnson, 2009).

\section{Crop-Water Productivity}

Weed-crop competition begins when crop plants and weeds grow in close proximity and their root or shoot system overlaps. In ricewheat system, due to enough soil moisture after harvesting of rice, weeds emerge earlier than wheat or along with wheat crop. Losses in wheat yield are primarily due to reduction in tillering. The average yield losses caused by weeds in different wheat growing zones ranges from 20 to $32 \%$. Water In irrigated environments, spatial and temporal variation of soil moisture offers opportunities for weed control. When the top layer of soil is dry, planting large-seeded crops into deep soil moisture can provide crops with an initial advantage over weeds. Another option under these conditions is to apply irrigation to germinate weeds, terminate them using herbicide, then plant the crop into the clean seed bed (Chauhan et al., 2012; Mulvaney et al., 2014).

Yield reductions due to weeds in wheat vary from $15-50 \%$, depending upon the weed density and type of weed flora (Jat et al., 2003). Uncontrolled weeds in wheat caused
$60.5 \%$ reduction in wheat grain yield under conventional tillage (CT) and $70 \%$ in zero-till (ZT) conditions. In extreme cases the losses caused by weeds can be up to complete crop failure (Malik and Singh, 1995). Improvement of grain and straw production encourages farmers to leave crop residues on their fields, and ensures the long-term benefit of ZT system. Minimum tillage + crop residue has been found to be beneficial for conserving water and improving crop productivity (Jat et al., 2012). Compared to deep tillage, conservation tillage in maize-wheat cropping system involving minimum tillage (in wheat) with Lantana camara mulch conserved more moisture, and resulted in higher grain yield of wheat in a hill ecosystem (Sharma and Acharya, 2000). The yields of wheat sown in presence of rice residues were always comparable to or higher than yields obtained under conventional sowing (Mishra and Singh, 2012). Direct-seeded rice required about 30-40\% less water and had 3-times less global warming potential compared with the transplanted rice crop.

In conclusion the findings of the various studies clearly indicated the weed stress on the productivity of rice-wheat cropping system. Out of the various management practices tillage systems and crop establishment may have positive effect on the suppression of weeds in rice-wheat cropping systems. Crop establishment with zero tillage (ZTDSR-ZT and ZTTPR-ZT) had positive impact of crop performance over conventional CTTPR-CT. Avoiding wet tillage (puddling) in rice fallowed by zero till wheat (NPTPRZT) also had advantage over CTTPR-CT, but not to that level of complete ZT-based systems. The different TCE practices in rice season also influenced the post-rainy season crop performance. Moreover, total weed seed density was lower under ZTDSR-ZT and ZTTPR-ZT systems than under CTTPR-CT system. It indicates that ZTDSR-ZT and 
ZTTPR-ZT systems can minimize weed infestation over time as long as there a high standard of weed management that minimizes seed return. Long-term adoption of conservation tillage (ZTTPR-ZT and ZTDSRZT) can minimize the weed severity and can be a sustainable crop management practice, as higher weed density in the initial years can exhaust the seed-bank. It is, therefore, concluded that conservation tillage-based crop establishment are sustainable strategies to upscale the crop productivity of rice-wheat rotation.

\section{References}

Anderson, R.L. 2005. A multi-tactic approach to manage weed population dynamics in crop rotations. Agron. J. 97: 1579-1583.

Arif Muhammad, Fazal Munsif, Muhammad Waqas, Ibni Amin Khalil and Kawsar Ali. 2007. Effect of tillage on weeds and economics of Fodder maize production. Pak. J. Weed Sci. Res. 13 (3-4): 167175.

Ball, D.A. 1992. Weed seed-bank response to tillage, herbicides, and crop rotation sequence. Weed Sci. 40: 654-659.

Barberi, P., and Lo Cascio, B. 2001. Long-term tillage and crop rotation effects on weed seed bank size and composition. Weed Res., 41: 325-340

Baraibar, B., Canadell, C., Torra, J., RoyoEsnal, A., and Recasens, J. 2017. Weed seed fate during summer fallow: the importance of seed predation and seed burial. Weed Sci. 65: 1-10.

Barroso, J., Navarrete, L., Sánchez del Arco, M., Fernandez-Qunitanilla, C., Lutman,P., Perry, N., and Hull, R. 2006. Dispersal of Avena fatua and Avena sterilis patchesby natural dissemination, soil tillage and combine harvesters. Weed Res. 46:118-128.

Bhatt, R., Kukal, S.S., Busari, M.A., Arora, S., and Yadav, M. 2016. Sustainability issues on rice-wheat cropping system. Int Soil Water Conser Res. 4: 64-74.
Boscutti, F., Sigura, M., Gambon, N., Lagazio, C., Krüsi, B.O., and Bonfanti, P. 2015. Conservation tillage affects species composition but not species diversity: a comparative study in Northern Italy. Environ. Manag. 55: 443-452.

Bostrom, U., and Fogelfors, H. 1999. Type and time of autumn tillage with and without herbicides at reduced rates in southern Sweden. Weed flora and diversity. Soil Tillage Res. 50:283- 293.

Brar, A. S., ans Walia, U. S. 2009. Weed dynamics and wheat (Triticum aestivum 1.) productivity as influenced by planting techniques and weed control practices. Indian J. Weed Sci. 41 (3 \& 4): 161-166.

Brust, G.E., and House, G.J. 1988. Weed seed destruction by arthropods and rodents in low-input soybean agro-ecosystems. Am. J. Altern. Agric. 3: 19-25.

Buhler,D.D., Hartzler, R.G., and Forcella, F.1997. Weed seed bank dynamics: implications to weed management. J. Crop Prod. 1: 145-168.

Buhler, D.D., Hartzler, R.G., and Forcella, F. 1997. Implications of weed seed-bank dynamics to weed management. Weed Sci. 45: 329-336.

Catizone, P., Tedeschi, M., and Baldoni, G. 1990. Influence of crop management on weed population and wheat yield. Proceeding of EWRS Symposium, Helsinki, Finland, 4-6, June 1990.

Chauhan, B.S., and Abugho, S.B. 2012. Interaction of rice residue and pre herbicides on emergence and biomass of four weed species. Weed Tech., 26: 627-632

Chauhan, B.S., Singh, R.G., and Mahajan, G. 2012. Ecology and management of weeds under conservation agriculture: A review. Crop Prot. 38: 57-65.

Chauhan, B.S., and Johnson, D.E. 2009. Influence of tillage systems on weed seedling emergence pattern in rainfed rice. Soil Tillage Res., 106: 15-21

Chauhan,B. S., and Johnson, D.E. 2010.The role of seed ecology in improving weed 
management strategies in the tropics. Adv Agron., 105: 221-262.

Chauhan, B.S., Gill, G. and Preston, C. 2006. Tillage system effects on weed ecology, herbicide activity and persistence: a review. Aust J Exp Agri., 46: 15571570.

Chauhan, B. S., Gill, G. S., and Preston, C. 2006. Seedling recruitment pattern and depth of recruitment of 10 weed species in minimum tillage and no-till seeding systems. Weed Sci., 54: 658-668.

Chauhan, B.S., Gill, G., and Preston, C. 2006. Influence of environmental factors on seed germination and seedling emergence of rigid ryegrass (Lolium rigidum).Weed Sci.54: 1004-1012.

Chauhan, B. S., Johnson, D. E. 2008. Germination ecology of southern crabgrass (Digitaria ciliaris) and India crabgrass (Digitaria longiflora): two important weeds of rice in tropics. Weed Sci., 56: 722-728.

Chauhan, B.S., Awanb, T.H., Abughoc, S.B., Evengelistab, G., and Yadav, S. 2015. Effect of crop establishment methods and weed control treatments on weed management, and rice yield. Field Crop Res., 172:72-84.

Chhokar, R.S., Sharma, R.K., Chauhan, D.S., and Mongia, A.D. 2006. Evaluation of herbicides against Phalaris minor in wheat in North-Western Indian plains. Weed Res., 46: 40-49.

Chhokar, R.S., and Sharma, R.K. 2008. Multiple herbicide resistance in littleseed canarygrass (Phalaris minor): A threat to wheat production in India. Weed Biol Manag 8: 112-123.

Chhokar, R.S., Sharma, R.K., Gathala, M.K., and Pundir, A.K. 2014. Effects of crop establishment techniques on weeds and rice yield. Crop Prot 64:7-12

Dorado, J., Del monte, J.P., and Lopez-Fando, C. 1999. Weed seed bank response to crop rotation and tillage in semiarid agro-ecosystems. Weed Sci. 47: 67-73.

Fernandez, R., Quiroga, A., Noellemeyer, E., Funaro, D., Montoya, J., Hitzmann, B., et al., 2008. A study of the effect of the interaction between site-specific conditions, residue cover and weed control on water storage during fallow. Agric Water Manag. 95: 1028-1040.

Franke, A.C., Singh, S., Mcroberts, N., Nehra, A.S., Godara, S., Malik, R.K., and Marshall, G. 2007. Phalaris minor seed bank studies: Longevity, seedling emergence and seed production as affected by tillage regime. Weed Res., 47: 73-83.

Garcia de Leon, D., Freckleton, R.P., Lima, M., Navarrete, L., Castellanos, E., and Gonzales-Andujar, J.L. 2014. Identifying the effect of density dependence, agricultural practices and climate variables on the long-term dynamics of weed populations. Weed Res. 54:556-564.

Gomez, R., Liebman, M., and Munkvold, G. 2013. Weed seed decay in conventional and diversified cropping systems. Storkey J, editor. Weed Res. 54: 13-25.

Heijting, S., Van der Werf, W., and Kropff, M. 2009. Seed dispersal by forage harvester and rigid-tine cultivator in maize. Weed Res. 49: 153-163.

Jat, M.L., Malik, R.K., Saharawat, Y.S., Gupta, R., Mal, B., and Paroda, R. 2012. Proceedings of Regional Dialogue on Conservation Agricultural in South Asia, New Delhi, India, 1-2 November, 2011. APAARI, CIMMYT, ICAR, 32 p

Jat, R.S., Nepalia, V., and Chaudhary, P.D. 2003. Influence of herbicide and methods of sowing on weed dynamics in wheat (Triticum aestivum). Indian $J$ Weed Sci., 35(1\&2): 18-20.

Kumar, V., Singh, S., Chhokar, R.S., Malik, R.K., Brainard, D.C., and Ladha, J.K. 2013. Weed management strategies to reduce herbicide use in zero-till ricewheat cropping systems of the IndoGangetic Plains. Weed Tech., 27: 241254.

Lal, B., Gautam, P., Raja, R., Tripathi, R., Shahid, M., Mohanty, S., Panda, B.B., Bhattacharyya, P.,and Nayak, A.K. 
2016. Weed seed bank diversity and community shift in a four-decade-old fertilization experiment in rice-rice system. Ecol. Eng. 286: 135-145.

Malik, R.K., and Singh, S. 1995. Littleseed canarygrass (Phalaris minor Retz.) resistance to isoproturon in India. Weed Technology 9: 419-425.

Mishra, J.S., and Singh, V.P. 2012. Tillage and weed control effects on productivity of a dry-seeded rice-wheat system on a Vertisol in Central India. Soil Tillage Res., 123:11-20.

Mohler, C.L. 1993. A model of the effects of tillage on emergence of weed seedlings. Ecol Appl. 3: 53- 73.

Mulugeta, D., and Stoltenberg, D.E. 1997. Increased weed emergence and seed bank depletion by soil disturbance in a no-till system. Weed Sci., 45: 234-241

Mulvaney, M., Verhulst, N., Herrera, J., Mezzalama, M., and Govaerts, B. 2014.Improved wheat performance with seed treatments under dry sowing on permanent raised beds. Field Crops Res. 164: 189-198.

Murphy, S.D., Clements, D.R., Belaoussoff, S., Kevan, P.G., and Swanton, C.J. 2006. Promotion of weed species diversity and reduction of weed seed-banks with conservation tillage and crop rotation. Weed Sci. 54:69-77.

Nandan, R., Singh, V., Singh, S.S., Kumar, V., Hazra, K.K., Nath, C.P., Poonia, S.P., and Malik, R.K. 2018a. Comparative assessment of the relative proportion of weed morphology, diversity, and growth under new generation tillage and crop establishment techniques in rice-based cropping systems. Crop Protect. 111: 23-32.

Nandan, R., Singh,V., Kumar, V.,Singh, S.S., Hazra, K.K., Nath, C.P., Malik, R.K., and Poonia, S.P. 2020.Viable weed seed density and diversity in soil and crop productivity under conservation agriculture practices in rice-based cropping systems. Crop Protect.,136:https://doi.org/ 10.1016/j. cropro.2020.105210

Nath, C.P., Das, T.K., Rana, K.S., Bhattacharyya, R., Pathak, H., Paul, S., Meena, M.C., Singh, S.B., 2017a. Weeds and nitrogen management effects on weeds infestation and crop productivity of wheat-mungbean sequence in conventional and conservation tillage practices. Agric. Res. 6, 33-46

Nichols, V., Verhulst, N., Cox, R., and Govaerts, B. 2015.Weed dynamics and conservation agriculture principles: A review. Field Crop Res. 183: 56-68.

Plaza, E.H., Kozak, M., Navarrete, L., and Gonzalez-Andujar, J.L. 2011. Tillage system did not affect weed diversity in a 23-year experiment in Mediterranean dryland. Agric. Ecosyst. Environ. 140: 102-105.

Punia, S.S., Singh, S., Yadav, A., Yadav, D.B., and Malik, R.K. 2016. Long-term impact of crop establishment methods on weed dynamics, water use and productivity in rice-wheat cropping system. Indian J. Weed Sci. 48: 158163.

Radheyshyam, Singh, R., Singh, V.K., and Guru, S.K. 2009. Effect of wheat establishment methods and weed management practices on weed dynamics and productivity of wheat grown in succession to rice. Indian $J$ Weed Sci., 41(1\&2): 70-72.

Sharma, P.K., and Acharya, C.L. 2000. Carryover of residual soil moisture with mulching and conservation tillage practices for sowing of rainfed wheat (Triticum aestivum L.) in north-west India. Soil Tillage Res., 57: 43-52

Sharma, P., Singh, M.K., Verma, K., and Prasad, S.K., 2020. Changes in the Weed Seed Bank in Long-Term Establishment Methods Trials under Rice-Wheat Cropping System. Agronomy 10 (2): 292; https://doi.org/10.3390/agronomy1 0020292

Shyam, R., Singh, R. and Singh, V. K. 2014. 
Effect of tillage and weed management practices on weed dynamics, weed seed bank and grain yield of wheat in ricewheat system. Indian $\mathrm{J}$ Weed Sci., 46(4): 322-325.

Singh, M., Bhullar, M.S., and Chauhan, B.S. 2015. Seed bank dynamics and emergence pattern of weeds as affected by tillage systems in dry direct seeded rice. Crop Prot. 67: 168-177.

Sinha, A.K., and Singh, R.P. 2005. Influence of cultivars under different tillage and weed management in wheat. Indian $J$ Weed Sci., 37(3\&4): 175-179.

Sosnoskie, L.M., Herms, C.P., and Cardina, J. 2006. Weed seed-bank community composition in a 35-yr-old tillage and rotation experiment. Weed Sci. 54: 263 273.

Swanton, C.J., Shrestha, A., Roy, R.C., BallCoelho, B.R., and Knezevic, S.Z.1999. Effect of tillage systems, N, and cover crop on the composition of weed flora. Weed Sci. 47:454-461.

Swanepoel, C.M., Habig, J., Thiebaut, N., and Swanepoel, L.H. 2015. Temporal variation in weed occurrence and biomass under conservation agriculture and conventional farming practices. Afr. J. Agric. Res., 10 (4): 3921-3929.

Thierfelder, C., and Wall, P.C. 2010. Weed control in smallholder conservation agriculture. Bulletin 6. CIMMYT. International Maize and Wheat Improvement Centre.

Travlos, I.S., Cheimona, N., Roussis, I., and Bilalis, D.J. 2018.Weed-species abundance and diversity indices in relation to tillage systems and fertilization. Front. Environ. Sci. 6: 11

Wall, P.C. 2008. Tailoring conservation agriculture to the needs of small farmers in developing countries. J. Crop Improv. 19:137-155.

Yadav, S.K., and Singh, G. 2005. Studies on the depth and periodicity of Phalaris minor emergence in wheat under different crop establishment methods. Indian J Weed Sci., 37(1\&2): 29-32.

\section{How to cite this article:}

Shivangi, Vivek, R. K. Naresh, D. K. Singh and Singh, P. K. 2020. Crop Establishment with Conservation Tillage on Viable Weed Seed Density and Diversity in Soil, Crop and Water Productivity under RWCS in North-West IGP: A Review. Int.J.Curr.Microbiol.App.Sci. 9(08): 676-690. doi: https://doi.org/10.20546/ijcmas.2020.908.074 